\title{
Construction and evaluation of an antibody phage display library targeting heparan sulfate
}

\author{
Lars A.A. Damen ${ }^{1}$ (D) - Els M.A. van de Westerlo ${ }^{1}$ E Elly M.M. Versteeg ${ }^{1}$. \\ Thierry van Wessel ${ }^{1}$ - Willeke F. Daamen ${ }^{1}$ (D) - Toin H. van Kuppevelt ${ }^{1}$ (I)
}

Received: 16 January 2020 / Revised: 30 March 2020 / Accepted: 13 April 2020 / Published online: 28 May 2020

(C) The Author(s) 2020

\begin{abstract}
Heparan sulfate (HS) is a linear polysaccharide with high structural diversity. Different HS epitopes have been detected and localized using single chain variable fragment ( $\mathrm{scFv}$ ) antibodies from a 'single pot' phage display library containing a randomized complementarity determining region of the heavy chain (CDR3). In this study, we created a new library containing anti-HS scFvs that all harbor a dp-38 heavy chain segment where the CDR3 region was engineered to contain the XBBXBX heparin binding consensus site $(\mathrm{X}=$ any amino acid, $\mathrm{B}=\mathrm{R}, \mathrm{K}$ or $\mathrm{H})$. The library contained $\sim 1.73 \times 10^{6}$ unique antibodies and was biopanned against HS from several sources. The selected antibodies were sequenced and chemically/immunohistologically characterized. A number of 67 anti-HS scFv antibodies were selected, of which 31 contained a XBBXBX CDR3 sequence. There was a clear preference for glycine at the first and proline at the fourth position of the CDR3. The sequence GZZP(R/K)X $(\mathrm{Z}=\mathrm{R}, \mathrm{K}$ or $\mathrm{H}$, but may also contain $\mathrm{N}, \mathrm{S}$, or $\mathrm{Q}$ ) was unusually overrepresented. Selected antibodies reacted with HS/heparin, but not with other glycosaminoglycans. Antibodies reacted differentially with respect to N-, 2-O, or 6-O-desulfated heparin preparations, and showed distinct topologies of HS epitopes in rat kidney sections. The library may be instrumental in the selection of a large pool of HS epitope-specific antibodies, and - since all antibodies differ only in their 6 amino acid CDR region - may be a tool for a rational design of antibodies recognizing specific HS sulfation patterns.
\end{abstract}

Keywords Heparan sulfate $\cdot$ Antibodies $\cdot$ Phage display library $\cdot$ Consensus site $\cdot$ Epitope

$\begin{array}{ll}\text { Abbreviations } \\ \text { BSA } & \text { Bovine serum albumin } \\ \text { CDR3 } & \begin{array}{l}\text { Complementarity determining region } 3 \text { of heavy } \\ \text { variable chain }\end{array} \\ \text { CSA } & \text { Chondroitin sulfate A } \\ \text { CSC } & \text { Chondroitin sulfate C } \\ \text { DNA } & \text { Deoxyribonucleic acid } \\ \text { DS } & \text { Dermatan sulfate } \\ \text { FR3 } & \text { Framework } 3 \text { of heavy variable chain } \\ \text { FR4 } & \text { Frame work } 4 \text { of heavy variable chain }\end{array}$

Electronic supplementary material The online version of this article (https://doi.org/10.1007/s10719-020-09925-z) contains supplementary material, which is available to authorized users.

Toin H. van Kuppevelt

Toin.vanKuppevelt@ radboudumc.nl

1 Department of Biochemistry, Radboud Institute for Molecular Life Sciences, Radboud university medical center, PO Box 9101, 6500 , HB Nijmegen, the Netherlands
HS Heparan sulfate
PBS phosphate buffered saline
$\mathrm{scFv} \quad$ Single chain variable fragment
$\mathrm{V}_{\mathrm{H}} \quad$ Heavy variable chain
$\mathrm{V}_{\mathrm{L}} \quad$ Light variable chain

\section{Introduction}

Heparan sulfate (HS) is a long heterogeneously sulfated glycosaminoglycan, predominantly present in the extracellular matrix and at the cell surface. During its biosynthesis, HS is modified by sulfation and epimerization reactions, resulting in a high structural and functional diversity $[1,2]$. Specific sulfation motifs within HS are involved in several physiological processes like cell signaling [2, 3], blood clotting [4], and pathological processes such as tumorigenesis [5] and Alzheimer's disease [6, 7]. However, it remains a challenge to identify and localize HS with specific structural motifs in tissues. With the development of the 'single pot' Nissim 
antibody phage-display library [8], many single chain variable fragment $(\mathrm{scFv})$ antibodies have been selected against different sources of HS [9-15]. These scFv antibodies consist of the variable part of the heavy $\left(\mathrm{V}_{\mathrm{H}}\right)$ and light chain $\left(\mathrm{V}_{\mathrm{L}}\right)$ of an immunoglobulin, joined together by a linker. In the Nissim library, the $\mathrm{V}_{\mathrm{H}}$ chain is variable, whereas the $\mathrm{V}_{\mathrm{L}}$ is fixed [8, 16]. About $45 \%$ of the $\mathrm{scFV}$ antibodies selected against HS harbor a $\mathrm{V}_{\mathrm{H}} \mathrm{dp}-38$ germline gene segment [13-15, 17-21]. The recognition of specific HS structures by antibodies from this library is primarily generated by the $\mathrm{V}_{\mathrm{H}}$ chain, especially the complementarity determining region 3 (CDR3) [8, 22]. The CDR3 is the region with most conformational variability and flexibility and is thought to have a major influence in epitope binding [11-14, 23, 24]. About $17 \%$ of the anti-HS antibodies published contain a heparin binding consensus site in the CDR3 region of the $\mathrm{V}_{\mathrm{H}}$ chain [13-15, 17-21]. Heparin binding consensus sites include $\mathrm{XBBXBX}, \mathrm{XBBBXXBX}$ and

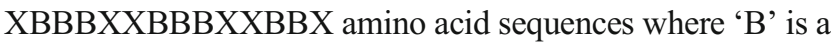
basic and ' $\mathrm{X}$ ' is a random amino acid residue $[13,25,26]$. These sequences are found in several, but not all, HS-binding proteins [25-28].

To expand the number of antibodies against HS, we here engineered and evaluated an antibody phage display library targeted for $\mathrm{HS}$ with a single $\mathrm{V}_{\mathrm{H}}$ germline segment (dp-38) and a CDR3 consisting of an XBBXBX heparin binding consensus site. As a template we used a previously obtained $\mathrm{scFv}$ antibody (HS4C3) which harbors both a dp-38 germline gene segment and a CDR3 sequence containing an XBBXBX heparin binding consensus site (GRRLKD) $[11,13]$.

\section{Materials \& methods}

\section{Construction of an antibody phage display library with a XBBXBX CDR3 sequence}

The phage display library was constructed to contain only scFv antibodies harboring the $\mathrm{V}_{\mathrm{H}} 3 \mathrm{dp}-38$ germline with an XBBXBX CDR3 amino acid sequence. Using the wellcharacterized HS4C3 scFv antibody from the Nissim library as template, the library was constructed in a series of 5 PCR procedures (PCR 1-PCR 5) (Fig. 1) [8, 13]. In all procedures, a general PCR mixture was used containing $50 \mathrm{mM} \mathrm{KCl}$, $10 \mathrm{mM}$ Tris- $\mathrm{HCl}$ (pH 9.0), 0.1\% Triton X-100, $1.5 \mathrm{mM}$ $\mathrm{MgCl}_{2}, 0.5 \mu \mathrm{M}$ primers (Table 1), 2.5 units Taq polymerase (Promega), and $0.75-1 \mathrm{mM}$ dNTP in a total volume of $50 \mu \mathrm{L}$. The cycling temperatures were $5 \mathrm{~min} 95^{\circ} \mathrm{C}$ followed by $25-$ 40 cycles of $1 \mathrm{~min}$ at $95{ }^{\circ} \mathrm{C}, 1 \mathrm{~min}$ at $46-50^{\circ} \mathrm{C}$ for annealing and $74{ }^{\circ} \mathrm{C}$ for $1.5-2 \mathrm{~min}$ for extension. Detailed PCR procedures are listed in Supplementary Table 1. In PCR 1, the $\mathrm{V}_{\mathrm{H}}$ (without the CDR3 and framework 4) of the HS4C3 gene was amplified. In PCR 2, the $\mathrm{V}_{\mathrm{L}}$ (including the c-Myc tag), the linker sequence and the framework 4 of the $\mathrm{V}_{\mathrm{H}}$ of the HS4C3 gene were amplified. The PCR 3 procedure was performed to introduce a new CDR3 into the $\mathrm{V}_{\mathrm{H}}$ gene using an 87 nucleotide degenerate reverse primer. This primer contained the CDR3 encoded as 5'-SNN NYK SNN NYK NYK SNN -3', where $\mathrm{S}$ encodes for $\mathrm{G}$ or $\mathrm{C}$; $\mathrm{Y}$ for $\mathrm{C}$ or $\mathrm{T}$; $\mathrm{K}$ for $\mathrm{G}$ or $\mathrm{T}$; and $\mathrm{N}$ for $\mathrm{A}, \mathrm{C}, \mathrm{G}$, or T, to obtain the XBBXBX sequence (Table 1). Next, we combined the new $\mathrm{V}_{\mathrm{H}}$ genes and the $\mathrm{V}_{\mathrm{L}}$ gene in PCR4 using overlapping sequences (FR4 of the $\mathrm{V}_{\mathrm{H}}$ ). The product of PCR 4 was evaluated on 1\% agarose gel and isolated using the QiaEX II agarose gel extraction kit (Qiagen $\mathrm{GmbH}$, Hilden, Germany). The purified product was amplified in PCR 5. The final product was purified after $1 \%$ agarose gel electrophoresis using phenol/chloroform extraction. DNA was precipitated using ethanol, the pellet was washed with $70 \%$ ethanol and dissolved in $50 \mu \mathrm{L}$ water. The final product was digested using NcoI and NotI restriction enzymes (Life Technologies BV, Breda, the Netherlands) and ligated overnight at $16^{\circ} \mathrm{C}$ into a $\mathrm{NcoI}$ and $\mathrm{NotI}$ digested pHEN1 vector (a kind gift of prof. G. Winter, Cambridge) using the Sureclone Ligation Kit (Amersham Pharmacia Biotech AB, Uppsala, Sweden). The ligation product was purified using phenol/ chloroform extraction. The ligation product was transformed via electroporation into $E$. coli $\mathrm{TG} 1$ (K12, sup E, hsd $\Delta 5$, thi, $\Delta$ (lac-proAB, $\mathrm{F}^{\prime}\left(\right.$ tra $\mathrm{D} 36$, proAB $^{+}$, lac $^{\mathrm{q}}$, lac$\mathrm{Z} \Delta \mathrm{M} 15$ ) electroporation competent cells, efficiency $\geq 1.0^{*} 10^{10} \mathrm{cfu} / \mu \mathrm{g}$ (Stratagene Cloning Systems, La Jolla, USA). To calculate the titer of transformants, dilutions of the original electroporated bacteria were plated onto $2 \mathrm{xTY}$ agar plates containing $0.1 \%(w / v)$ ampicillin and $1 \%(\mathrm{w} / \mathrm{v})$ glucose and incubated overnight at $37^{\circ} \mathrm{C}$.

\section{Random selection of clones}

The library was plated on large $2 \mathrm{xTY}$ agar plates containing $0.1 \%(\mathrm{w} / \mathrm{v})$ ampicillin and $1 \%(\mathrm{w} / \mathrm{v})$ glucose and incubated overnight at $37{ }^{\circ} \mathrm{C}$. Subsequently, 240 clones were randomly picked from the plate and cultured overnight in LB medium containing $1 \%(\mathrm{w} / \mathrm{v})$ glucose and $0.1 \%(\mathrm{w} / \mathrm{v})$ ampicillin. Plasmid DNA was collected using the QIAprep spin Miniprep Kit (Qiagen, Leusden, the Netherlands) and the $\mathrm{V}_{\mathrm{H}}$ and CDR3 was sequenced using the PelB, forlinkseq and VL3 primer (Table 1).

\section{Selection of new scFv antibodies}

Phage display biopanning procedures was performed as described previously [10]. Tubes were coated by incubation with $10 \mu \mathrm{g} / \mathrm{mL}$ HS from bovine kidney (Seikagaku Kogyo Co, Tokyo, Japan), HS from intestinal mucosa (Sigma), or HS isolated from human lung [17], all in $90 \%(w / v)$ $\left(\mathrm{NH}_{4}\right)_{2} \mathrm{SO}_{4}$ [29]. Phages were produced from the library by addition of helper phage VCS-M13 (Stratagene, La Jolla, CA). Phages were precipitated and isolated using $20 \%$ 


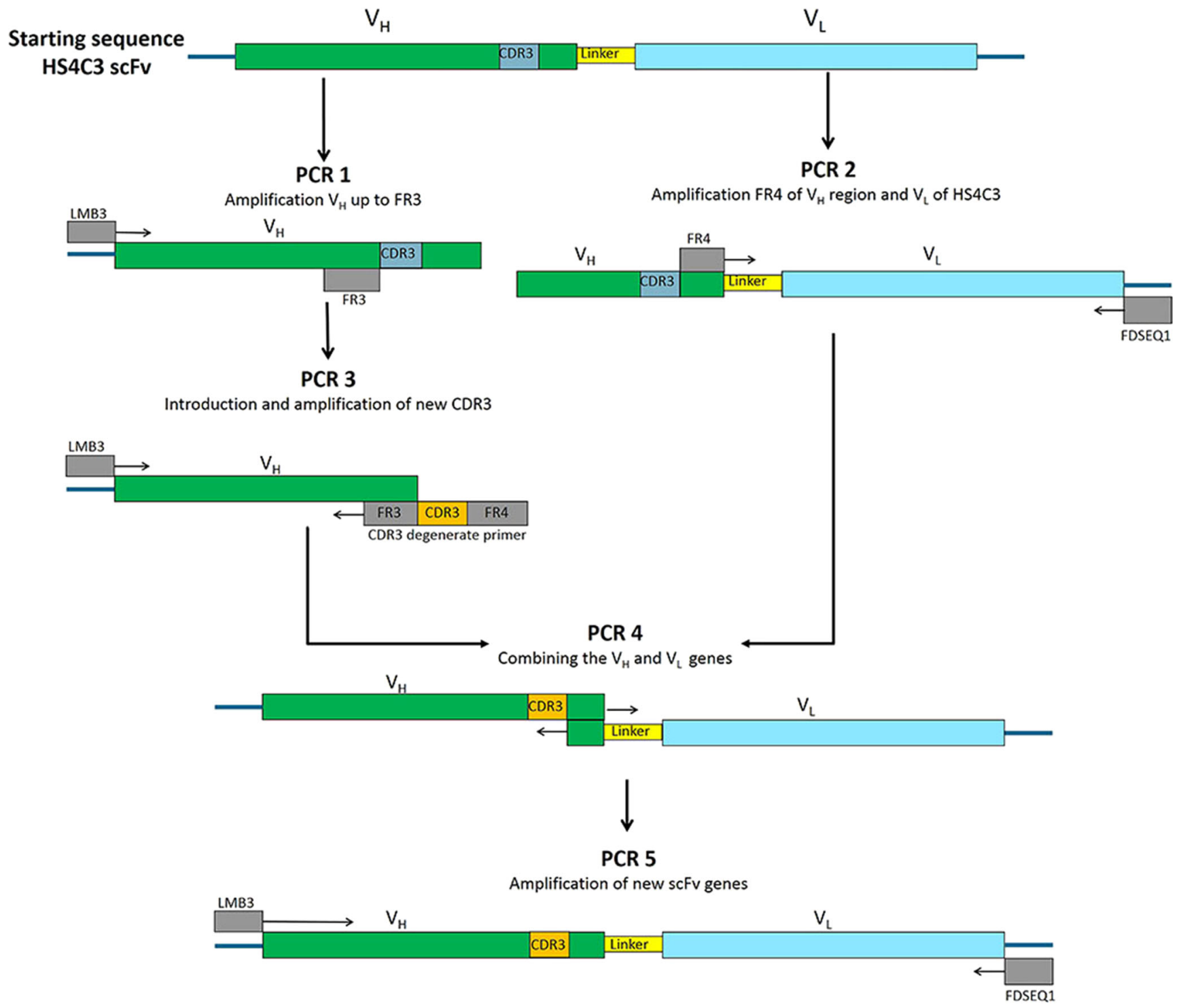

Fig. 1 Schematic overview of PCR reactions used to construct the XBBXBX CDR3 antibody library. In PCR 1, the heavy variable chain $\left(V_{H}\right)$ up to framework 3 (FR3) of the HS4C3 coding sequence was amplified. In PCR 2, framework 4 (FR4) of $\mathrm{V}_{\mathrm{H}}$ and the light variable chain $\left(V_{L}\right)$ of the HS4C3 coding sequence was amplified. The XBBXBX complementarity determining region 3 (CDR3) was engineered using the degenerate oligonucleotide CDR3 primer in PCR 3. The new $\mathrm{V}_{\mathrm{H}}$ genes were combined with the $V_{L}$ gene in PCR 4 and subsequently amplified in PCR 5. Note that the CDR3 primer contains, next to the CDR3 region, the FR4 region and part of the FR3 region. For primers, see Table 1. scFv: single chain variable fragment antibody.

\section{Initial screening for unique antibodies against HS}

tubes. Phages were allowed to bind for $2 \mathrm{~h}$ under rotation. Non-bound phages were washed away, and bound phages were eluted with $1 \mathrm{~mL} 100 \mathrm{mM}$ triethylamine for $10 \mathrm{~min}$. In some cases, the 10 min step was followed by an additional 20 min elution step with $1 \mathrm{~mL} 100 \mathrm{mM}$ triethylamine, to retrieve phages that remained bound in the first elution step. The triethylamine was neutralized by addition of $0.5 \mathrm{~mL} 1 \mathrm{M}$ Tris- $\mathrm{HCl}(\mathrm{pH} 7.3)$. TG1 cells were infected with the collected phages and plated onto $2 \mathrm{xTY}$ agar plates containing $0.1 \%$ $(w / v)$ ampicillin.
Screening of $\mathrm{scFv}$ was performed as described previously [10, 13]. A 96-wells flat-bottom polystyrene plate was incubated overnight with $100 \mu \mathrm{L}$ of $90 \%(w / v)\left(\mathrm{NH}_{4}\right)_{2} \mathrm{SO}_{4}$ containing $10 \mu \mathrm{g} / \mathrm{mL}$ HS from bovine kidney (Seikagaku), HS from porcine intestinal mucosa, heparin from porcine intestinal mucosa, dermatan sulfate from pig skin, chondroitin sulfate A (CSA) from bovine trachea, chondroitin sulfate $\mathrm{C}$ (CSC) from shark cartilage, thymus DNA, and hyaluronic acid from rooster comb (all from Sigma, St. Louis, MO). After washing, 
Table 1 Oligonucleotide sequences used for construction of the XBBXBX CDR3 phage display library and sequencing of $\mathrm{scFv}$ antibody genes

\begin{tabular}{ll}
\hline $\begin{array}{l}\text { Primer } \\
\text { name }\end{array}$ & Sequence \\
\hline LMB 3 & 5'- CAG GAA ACA GCT ATG AC -3' \\
FR3 & 5'- TCT TGC ACA GTA ATA CAC GGC CGT GTC -3' \\
FDSEQ1 & 5'- GAA TTT TCT GTA TGA GG -3' \\
FR4 & 5'- TGG GGC CAA GGT ACC CTG GTC ACC GTC TCG AGA GGT GGA GGC -3' \\
CDR3 primer & 5'- GCC TCC ACC TCT CGA GAC GGT GAC CAG GGT ACC TTG GCC CCA SNN \\
& NYK SNN NYK NYK SNN TCT TGC ACA GTA ATA CAG GGC CGT GTC -3' \\
Forlinkseq & 5'- GCC ACC TCC GCC TGA ACC -3' \\
VL3 & 5'- CTT GGC ATG TGA TCC TGA -3' \\
PelB & 5'- CCG CTG GAT TGT TAT TAC TC -3' \\
\hline
\end{tabular}

${ }^{\mathrm{a}} \mathrm{S}=[\mathrm{G}, \mathrm{C}], \mathrm{N}=[\mathrm{A}, \mathrm{G}, \mathrm{C}, \mathrm{T}], \mathrm{Y}=[\mathrm{C}, \mathrm{T}], \mathrm{K}=[\mathrm{G}, \mathrm{T}]$ plates were blocked with $3 \%(w / v)$ bovine serum albumin (BSA) in $0.01 \mathrm{M}$ phosphate buffered saline $\mathrm{pH} 7.2$ (PBS) with $1 \%(v / \mathrm{v})$ Tween 20 for $60 \mathrm{~min}(200 \mu \mathrm{L} /$ well). After induction of picked clones in $200 \mu \mathrm{L} 2 \mathrm{xTY}$ with $0.1 \%(w / v)$ glucose and $0.1 \%(\mathrm{w} / \mathrm{v})$ ampicillin in a 96-wells polystyrene plate, plates were centrifuged and $50 \mu \mathrm{L}$ of the supernatant was mixed with PBS with $0.1 \%(\mathrm{v} / \mathrm{v})$ Tween $20($ PBST) containing 2\% (w/v) BSA in each well and incubated for $2 \mathrm{~h}$. Bound antibodies were detected using a mouse monoclonal antibody against the c-Myc tag (9E10), followed by a goat-anti-mouse IgG conjugated with alkaline phosphatase (Dako Agilent, Santa Clara, CA) in $1 \%(w / v)$ BSA/PBST. Enzyme activity was detected by addition of $100 \mu \mathrm{L}$ of $1 \mathrm{mg} / \mathrm{mL}$ p-4-nitrophenylphosphate in $1 \mathrm{mM}$ diethanolamine, with $0.5 \mathrm{mM} \mathrm{MgCl} 2, \mathrm{pH} 9.8$. Absorbance was measured at $405 \mathrm{~nm}$. Positive clones were inoculated in $15 \mathrm{~mL}$ LB-medium $(0.1 \%(\mathrm{w} / \mathrm{v})$ ampicillin and $1 \%(w / v)$ glucose $)$ and cultured overnight at $37^{\circ} \mathrm{C}$. Plasmid DNA was collected using the QIAprep spin Miniprep Kit (Qiagen, Leusden, the Netherlands) and the CDR3 was sequenced using the PelB, forlinkseq and VL3 primers (Table 1).

\section{Large-scale antibody production}

For further characterization of the antibodies, $\mathrm{scFv}$ were obtained from the periplasmic fraction as described [13]. Bacteria were grown overnight at $37^{\circ} \mathrm{C}$ in $15 \mathrm{~mL}$ LB-medium $(100 \mu \mathrm{g} / \mathrm{mL}$ ampicillin and $1 \%(w / v)$ glucose). Subsequently, $10 \mathrm{~mL}$ of the overnight culture was added to $1 \mathrm{~L}$ induction medium (2xTY medium containing $0.1 \%(\mathrm{w} / \mathrm{v})$ glucose and $0.1 \%(\mathrm{w} / \mathrm{v})$ ampicillin). At an $\mathrm{OD}_{600}$ of 0.6 , the antibody expression was induced by addition of isopropyl- $\beta$-D-thiogalactopyranoside (IPTG, UBPBio, Oxfordshire, UK) in a final concentration of $1 \mathrm{mM}$, and incubated for three $\mathrm{h}$ at $30{ }^{\circ} \mathrm{C}$. The cultures were centrifugated for $15 \mathrm{~min}$ at $3561 \mathrm{~g}$ to separate bacteria from culture medium. Bacterial pellet was resuspended and incubated for $15 \mathrm{~min}$ on ice in $10 \mathrm{~mL} 0.2 \mathrm{mM}$ sodium borate buffer (pH 8.0) containing $0.16 \mathrm{M} \mathrm{NaCl}$ to accommodate osmotic shock. This buffer was enriched with protease inhibitors (10 mM N-ethylmaleimide, $100 \mathrm{mM}$ 6-amino hexane acid, $10 \mathrm{mM}$ benzamidine- $\mathrm{HCl}, 5 \mathrm{mM}$ iodoacetamide, $0.15 \mu \mathrm{M}$ pepstatin, $30 \mathrm{nM}$ apoprotein, and $100 \mu \mathrm{M}$ phenylmethylsulfonyl fluoride), supplemented with $1 \%(w / v) \mathrm{NaN}_{3}$. After centrifugation for $15 \mathrm{~min}$ at $10,000 \mathrm{~g}$ at $4{ }^{\circ} \mathrm{C}$, supernatant was passed over a PBS wetted $0.45 \mu \mathrm{m}$ filter and subsequently dialyzed against PBS, using a Visking 12-14 kDa MWCO dialysis hose (VWR, Amsterdam, NL).

\section{Characterization of scFv antibodies}

ELISA. Epitope specificity of the $\mathrm{scFv}$ antibodies was further analyzed using an ELISA setting. The wells of a 96-wells flat bottom polystyrene microplate (Greiner Bio-One, Alphen aan de Rijn, the Netherlands) were coated by incubating with $100 \mu \mathrm{L}$ of $90 \%(w / v)\left(\mathrm{NH}_{4}\right)_{2} \mathrm{SO}_{4}$ containing $10 \mu \mathrm{g} / \mathrm{mL}$ heparin, $\mathrm{N}$-desulfated/ $\mathrm{N}$-acetylated heparin, 2- $O$ desulfated heparin or 6-O desulfated heparin (kind gifts of dr. A. Naggi and prof. Casu of the G. Ronzoni Institute for Chemical and Biochemical Research, Milan, Italy [30, 31]). Composition of the modified heparins are listed in Supplementary Table 2 [31]. Plates were washed with PBST and blocked with 3\% $(\mathrm{w} / \mathrm{v})$ BSA with $1 \%(\mathrm{v} / \mathrm{v})$ Tween 20 in PBS. Periplasmic fractions containing the $\mathrm{scFv}$ antibodies were diluted $1: 1$ in $1 \%$ $(w / v)$ BSA/PBST and incubated for $1.5 \mathrm{~h}$. Bound $\mathrm{scFv}$ antibodies were detected as described above, using mouse anti-cMyc antibody 9E10 and alkaline phosphatase conjugated goat anti-mouse antibodies, and visualized using alkaline phosphatase substrate disodium p-4-nitrophenylphosphate.

Immunohistochemistry. Rat kidney specimens (Wistar, male) were snap-frozen in liquid isopentane and stored at $-80{ }^{\circ} \mathrm{C}$. Cryo sections $(5 \mu \mathrm{m})$ were rehydrated and blocked in 1\% $(w / v)$ BSA/PBST for $60 \mathrm{~min}$ and incubated with selected scFv antibodies in 1\%(w/v) BSA/PBST for $90 \mathrm{~min}$, with antibody $\mathrm{HS} 4 \mathrm{C} 3$ as a positive control. ScFvs were detected by a 45 min incubation with mouse monoclonal anti c-Myc antibody $9 \mathrm{E} 10(1: 10)$ in $1 \%(\mathrm{w} / \mathrm{v}) \mathrm{BSA} / \mathrm{PBST}$, followed by a 45 min incubation with goat anti-mouse IgG, Alexa 448 conjugated (Molecular Probes Inc.) (1:300) in 1\% (w/v) BSA/ PBST. After each incubation, sections were washed in PBST $(3 \times 5 \mathrm{~min})$. Sections were fixated in $100 \%$ ethanol, air-dried and embedded in 10\% (w/v) Mowiol in $0.1 \mathrm{M}$ Tris- 
$\mathrm{HCl}, \mathrm{pH} 8.5,25 \%(v / \mathrm{v})$ glycerol and $2.5 \%(\mathrm{w} / \mathrm{v}) \mathrm{NaN}_{3}$. Sections were examined using a Leica DM 6000 fluorescence microscope and images were obtained using the Leica Microsystems software.

\section{Results}

\section{Library}

The library was constructed using a degenerated primer, aimed to introduce a new CDR3 consisting of an XBBXBX heparin binding consensus sequence. The primer design was such that there is a $62.5 \%$ chance of a basic amino acid $(\mathrm{R}, \mathrm{K}$ or $\mathrm{H})$ at the ' $\mathrm{B}$ ' site, the other possibilities being $\mathrm{Q}, \mathrm{S}$ or $\mathrm{N}$. The latter amino acids are also frequently involved in the binding of heparin/HS [25, 32]. The theoretical diversity of the library is $1.34 \times 10^{8}$ unique clones, encoding for $1.73 \times 10^{6}$ unique full-length proteins. To obtain an impression of the actual diversity of the library, 222 randomly picked clones were sequenced, yielding 194 full sequences of which 189 (97.4\%) were unique (Table 2, Supplementary Table 3). This indicates that the library contains about $1.31 \times 10^{8}$ clones encoding for $1.68 * 10^{6}(97 \%$ of $1.73 \times$ $10^{6}$ ) unique full-length proteins, which is $97 \%$ of the theoretical diversity. Screening of CDR3 sequences demonstrated that $23.3 \%(44 / 194)$ of the randomly selected clones contained a XBBXBX amino acid sequence, similar to what was theoretically estimated (24.4\%) (Table 2). Selection against HS (see below) yielded 67 unique scFv antibodies (Table 3). The XBBXBX CDR3 was more abundant in the $\mathrm{scFv}$ selected against HS $(46 \%, 33 / 67)$ than in randomly picked clones $(23.3 \%)$ $(p<0.01)$ (Table 2). In addition, 35 of the $67(52 \%)$ scFv antibodies selected against $\mathrm{HS}$ had glycine $(\mathrm{G})$ as the first amino acid residue, and 30 of the $67(44.5 \%)$ contained proline $(\mathrm{P})$ as the fourth amino acid residue (Table 4). A combination of $\mathrm{G}$ at the first position and $\mathrm{P}$ at the fourth, together with a $\mathrm{R}$ or $\mathrm{K}$ at the fifth position, was observed 23 times (34.4\%) (Table 2). This combination was completely absent in randomly selected clones (theoretically $0.2 \%$ of all clones harbor this sequence (Table 2)).

\section{Biopanning of library against various HS and characterization of antibodies}

After biopanning against immobilized HS, 25 unique antibodies were selected against bovine kidney (10 min elution), and 30 after an additional 20 min elution (Table 3). Further, 5 antibodies were selected against HS from human lung, and 7 against porcine intestinal mucosa after 10 min elution (Table 3). The reactivity of all antibodies with various types of glycosaminoglycans and modified heparin preparations was determined (Supplementary Table 4 and 5), as well as the location of antibody-defined HS epitopes in the kidney (Supplementary Table 6). To illustrate the characteristics of some anti-HS antibodies, we here highlight two antibodies selected against bovine kidney after 10 min elution (MP3C1 and MP4A11'10.b.k.), two against bovine kidney after an additional 20 min elution (MP4F11 and MP3B2'20.b.k.), two against HS from porcine mucosa (MP4G5, and MP3G7), and one against human lung HS (MP3A5) (Table 3). One randomly picked scFv antibody (MPB49) that was not reactive with HS was also included. Antibody specificity was screened using ELISA. Anti-HS antibodies were moderate to strong binders to heparin (Table 5). All antibodies were moderate to strong binders to HS from bovine kidney, whereas antibodies MP4G5 and MP4F11 showed strong binding towards HS from intestinal mucosa. Antibodies were not reactive with other glycosaminoglycans (chondroitin sulfate $\mathrm{A}$ and $\mathrm{C}$, dermatan sulfate, hyaluronic acid) and DNA, with the exception of MP4F11 which showed moderate binding to dermatan sulfate (Table 5).

\section{Analysis of sulfate groups in HS-epitope of scFv antibodies}

Reactivity of the anti-HS antibodies was further studied using modified heparin preparations $(\mathrm{N}$-desulfated/ $\mathrm{N}$-acetylated, 2$O$ desulfated, and 6- $O$ desulfated heparin; Table 6). Reactivity of MP4F11 and MP3G7 was observed towards all desulfated forms of heparin, indicating that both antibodies recognize
Table 2 Diversity of the XBBXBX CDR3 antibody library

\begin{tabular}{lll}
\hline & $\begin{array}{l}\text { Randomly } \\
\text { picked clones }\end{array}$ & $\begin{array}{l}\text { Clones selected } \\
\text { against heparan sulfate }\end{array}$ \\
\hline Number of clones selected & 222 & 67 \\
Full length CDR3 $\mathrm{V}_{\mathrm{H}}$ DNA sequence (\% of selected clones) & $194(87.3 \%)$ & $67(100 \%)$ \\
Unique CDR3 $\mathrm{V}_{\mathrm{H}}$ DNA sequence & $189(97.4 \%)$ & $67(100 \%)$ \\
XBBXBX $^{\mathrm{a}}$ sequence of CDR3 $\mathrm{V}_{\mathrm{H}}(\%$ of unique sequences) & $44(23.3 \%)^{\mathrm{b}}$ & $31(46 \%)^{\mathrm{b}}$ \\
GZZP(R/K)X $\mathrm{X}^{\mathrm{c}}$ sequence of CDR3 $\mathrm{V}_{\mathrm{H}}(\%$ of unique sequences) & $0^{\mathrm{d}}$ & $23(34.3 \%)^{\mathrm{d}}$ \\
\hline
\end{tabular}

a ' $\mathrm{B}$ ' encodes the basic residues $\mathrm{H}, \mathrm{R}$, or $\mathrm{K}$, and ' $\mathrm{X}$ ' encodes any amino acid

${ }^{\mathrm{b}}$ Theoretical value: $24.4 \%$

c 'Z' encodes H, R, K, N, Q, or S

${ }^{\mathrm{d}}$ Theoretical value: $0.2 \%$ 
Table 3 Overview of scFv antibodies selected against HS preparations using the XBBXBX CDR3 antibody library

\begin{tabular}{|c|c|c|c|c|c|c|c|}
\hline \multicolumn{2}{|c|}{$\begin{array}{l}\text { HS bovine kidney } 10 \mathrm{~min} \\
\text { elution }\end{array}$} & \multicolumn{2}{|c|}{$\begin{array}{l}\text { HS bovine kidney } 20 \mathrm{~min} \\
\text { elution }^{\mathrm{a}}\end{array}$} & \multicolumn{2}{|c|}{ HS intestinal mucosa } & \multicolumn{2}{|c|}{ HS human lung } \\
\hline scFv name & CDR3 & scFv name & CDR3 & scFv name & CDR3 & scFv name & CDR3 \\
\hline MP4F5 & TRRLKS & MP3E5 & WRQRQA & MP3D9 & LRRAQP & MP3H3 & GRRHSA \\
\hline MP4F10 & SRRHRS & MP4E8 & VRRSRT & MP3A11 & GSRLRR & MP4A9 & GQRMKH \\
\hline MP3C1 & SRRHKN & MP4H12 & TRRPKT & MP4H8 & GRKPRT & MP3F5 & GQRHSA \\
\hline MP3H1 & RRNPKL & MP4B11 & TRKPRR & MP4G5 & GRKPRL & MP3D6 & GNRLRS \\
\hline MP3C8 & RRHPQR & MP3C2 & TKHQKR & MP3A4 & GKSPRK & MP3A5 & GNQQRH \\
\hline MP4B9 & NRRSKT & MP4B9 & SRNTKA & MP3G7 & GKQPRK & & \\
\hline MP3D5 & MRKTHT & MP4G9 & RRQPRT & MP3B9 & GKKPRR & & \\
\hline MP3H10 & IRSLKP & MP3B2 & NRRHRT & & & & \\
\hline MP3C2 & GSKQRV & MP4B12 & NRRARQ & & & & \\
\hline MP3G6 & GSKPRR & MP3B4 & NRKHNR & & & & \\
\hline MP4G3 & GSKPRM & MP4E10 & MRRSNP & & & & \\
\hline MP3A10 & GSKPRI & MP4A11 & MRRLRP & & & & \\
\hline MP4A4 & GRRPRV & MP4E11 & MRRAQP & & & & \\
\hline MP4C6 & GRRNHV & MP4H10 & LRRHHN & & & & \\
\hline MP4H8 & GRQPRV & MP3E1 & LRNPRN & & & & \\
\hline MP4A11 & GRQPKR & MP3E6 & IRSKDQ & & & & \\
\hline MP3B2 & GRKPRV & MP3H4 & IRRLSS & & & & \\
\hline MP3D2 & GQRPRA & MP3D6 & IRKIKK & & & & \\
\hline MP3D9 & GQRKRT & MP3C6 & IRHART & & & & \\
\hline MP3G2 & GQKPRH & MP3C3 & IKRLHS & & & & \\
\hline MP3E7 & GQHPRR & MP4H7 & GRRPRT & & & & \\
\hline MP3F1 & GKRPRS & MP4E7 & GRRPRF & & & & \\
\hline MP3G12 & GKQPRA & MP4F9 & GRRPKR & & & & \\
\hline MP3D6 & GHSPRL & MP4F11 & GRRLRK & & & & \\
\hline \multirow[t]{6}{*}{ MP3B3 } & GHKPRH & MP3G1 & GRKPRR & & & & \\
\hline & & MP4A9 & GQRLRR & & & & \\
\hline & & MP4C11 & GQKSRK & & & & \\
\hline & & MP4A7 & ERRPKL & & & & \\
\hline & & MP4G11 & ERRHRT & & & & \\
\hline & & MP3G2 & ARHIQT & & & & \\
\hline
\end{tabular}

Antibodies highlighted in yellow contain a XBBXBX CDR3 sequence; antibodies in red contain a GZZP(R/K)X CDR3 sequence, where ' $\mathrm{B}$ ' encodes the basic residues $\mathrm{H}, \mathrm{R}$, or $\mathrm{K}$; ' $\mathrm{X}$ ' encodes any amino acid and ' $\mathrm{Z}$ ' encodes $\mathrm{H}, \mathrm{R}, \mathrm{K}, \mathrm{N}, \mathrm{Q}$, or S.

${ }^{a}$ the 20 min. elution was performed after an initial 10 min elution.

HS: heparan sulfate

heparan sulfate with a moderate degree of sulfation. In contrast, MP3B2'20.b.k. did not react with the modified heparin molecules, indicating its preference for much higher sulfated forms of HS. The MP4G5 and MP3A5 antibodies did not react with 2-O desulfated and $\mathrm{N}$-desulfated/N-acetylated forms of heparin, but were able to detect the 6- $O$ desulfated form of heparin (note that in this heparin preparation about $30 \%$ of the 6-O sulfate groups are still present). MP4A11'10.b.k. was able to detect both 6-O desulfated and 2- $O$ desulfated heparin, but did not bind to the $\mathrm{N}$-acetylated form of heparin, indicating $\mathrm{N}$ - sulfation to be essential for binding.

\section{Localization of HS epitopes in rat kidney sections}

The location of the epitope defined by the anti-HS scFv antibodies was analyzed in rat kidney cryosections and compared to the original HS4C3 antibody. Although all scFvs have a unique CDR3 sequence, three main patterns of staining were observed (Fig. 2, Table 7). MP3C1 (Fig. 2A), MP3B2'20.b.k. and MP3A5 mainly stained the glomerulus and the peritubular capillaries, while MP4A11'10.b.k. (Fig. 2B) and MP3G7 primarily recognized Bowman's capsule. Both Bowman's capsule and the glomerulus were recognized by MP4F11 (Fig. 2C), MP4G5 and MP4F11). Antibody MPB49 (randomly selected) was not reactive with kidney sections (Fig. 2E).

\section{Discussion}

\section{Library development}

In this study, we successfully developed a new antibody phage display library designed to target HS by engineering the CDR3 in 
Table 4 Occurrence (in \%) of specific amino acids in the CDR3 of antiHS scFv antibodies

\begin{tabular}{|c|c|c|c|c|c|c|}
\hline \multirow[b]{2}{*}{ Amino acid } & \multicolumn{6}{|c|}{ Position in the CDR3 $V_{H}$} \\
\hline & $\mathrm{X}$ & $\mathrm{B}^{\mathrm{a}}$ & $\mathrm{B}^{\mathrm{a}}$ & $\mathrm{X}$ & $\mathrm{B}^{\mathrm{a}}$ & $\mathrm{X}$ \\
\hline A & 1.5 & & & 6.0 & & 9.0 \\
\hline \multicolumn{7}{|l|}{$\mathrm{D}$} \\
\hline $\mathrm{N}$ & 6.0 & 3.0 & 4.5 & 1.5 & 6.0 & 4.5 \\
\hline $\mathrm{R}$ & 4.5 & 64.0 & 47.5 & 1.5 & 56.5 & 17.8 \\
\hline \multicolumn{7}{|l|}{$\mathrm{C}$} \\
\hline Q & & 12.0 & 10.5 & 4.5 & 7.5 & 3.0 \\
\hline $\mathrm{E}$ & 3.0 & & & & & \\
\hline G & 52.0 & & & & & \\
\hline $\mathrm{H}$ & & 3.0 & 7.5 & 12.0 & 6.0 & 6.0 \\
\hline I & 9.0 & & & 3.0 & & 1.5 \\
\hline $\mathrm{L}$ & 4.5 & & & 13.5 & & 6.0 \\
\hline $\mathrm{K}$ & & 10.5 & 24.0 & 3.0 & 18.0 & 7.5 \\
\hline M & 6.0 & & & 1.5 & & \\
\hline $\mathrm{F}$ & & & & & & 3.0 \\
\hline $\mathrm{P}$ & & & & 44.5 & & 7.5 \\
\hline S & 4.5 & 7.5 & 6.0 & 6.0 & 9.0 & 9.0 \\
\hline $\mathrm{T}$ & 6.0 & & & 3.0 & & 17.8 \\
\hline W & 1.5 & & & & & \\
\hline \multicolumn{7}{|l|}{ Y } \\
\hline V & 1.5 & & & & & 7.5 \\
\hline Total & $100 \%$ & $100 \%$ & $100 \%$ & $100 \%$ & $100 \%$ & $100 \%$ \\
\hline
\end{tabular}

a 'B' may contain basic residues $(\mathrm{R}, \mathrm{K}, \mathrm{H})$, but also $\mathrm{Q}, \mathrm{N}$, or $\mathrm{S}$

the $\mathrm{V}_{\mathrm{H}}$ of the antibodies. The CDR3 is thought to be the largest contributor to antigen recognition and in this study we designed it to contain a heparin binding consensus site [33]. In proteins, XBBXBX, XBBBXXBX, and XBBBXXBBBXXBBX sequences have been described as heparin binding consensus sites [26]. We selected the XBBXBX sequence, since a number of the previously obtained anti-HS scFvs contain short $(<10$ amino acids) CDR3 sequences, which may be favorable for binding $[13,14,34]$. To engineer the XBBXBX CDR3, we used a degenerate primer, which also allowed $\mathrm{S}, \mathrm{N}$, and $\mathrm{Q}$ in the ' $\mathrm{B}$ ' positions. As a result, $23.5 \%$ of our library contained the actual XBBXBX amino acid sequence in the CDR3. The XBBXBX consensus site is not essential for protein-HS interaction, although many proteins use it $[28,35]$. Of the selected anti-HS antibodies $46 \%$ contained a XBBXBX CDR3 sequence. The presence of $\mathrm{S}, \mathrm{N}$, or $\mathrm{Q}$ at the 'B' positions of the CDR3 was found in a number of anti-HS scFv antibodies indicating that the XBBXBX is not an absolute requirement for binding. Interestingly, these residues have been described in heparinbinding peptides [25], and a number of previously obtained anti-HS scFv antibodies contain these residues within their CDR3 [12-15].

When evaluating the ' $\mathrm{X}$ ' residues within the $\mathrm{XBBXBX}$ CDR3 of anti-HS scFvs, an abundance of $\mathrm{G}$ and $\mathrm{P}$ at the first and fourth position respectively, was noticed. These residues have been described to provide structural stability to a loop structure in the CDR3 [36]. Moreover, these residues have been frequently found in heparin-binding peptides alongside $\mathrm{R}, \mathrm{K}, \mathrm{H}, \mathrm{S}, \mathrm{N}$, and Q [25]. Anti-HS scFv antibodies from the library seem to have a preference for the GZZP(R/K)X sequence, where ' $Z$ ' encodes R, K, H, S, N, or Q. Since the amino acids $\mathrm{G}$ and $\mathrm{P}$ are frequently found in turns, bends and folds [37-40] the GZZP(R/K)X sequence may form a charged pocked structure that binds to a specific monosaccharide or a specific spatial orientation of sulfate groups, which are generally present on the outside of a HS molecule. The G and $\mathrm{P}$ would then contribute to the formation of a pocket, and the positively charged amino acids would confer binding to the negatively charged saccharide.

Table 5 Reactivity of selected anti-HS scFv antibodies against several glycosaminoglycans as assessed by ELISA

\begin{tabular}{|c|c|c|c|c|c|c|c|c|}
\hline & MP3C1 & MP4A11 & $M P 3 B 2^{b}$ & MP4F11 & MP3G7 & MP4G5 & MP3A5 & MPB49 \\
\hline Heparin & ++ & +++ & + & +++ & +++ & +++ & + & - \\
\hline HS b.k. & ++ & + & ++ & ++ & +++ & +++ & + & - \\
\hline HS i.m. & - & + & \pm & ++ & + & ++ & \pm & - \\
\hline DS & - & - & - & + & - & - & - & - \\
\hline CSA & - & - & - & - & - & - & - & - \\
\hline $\mathrm{CSC}$ & - & - & - & - & - & - & - & - \\
\hline DNA & _ & - & _ & _ & - & - & - & - \\
\hline
\end{tabular}

Reactivity: +++: very strong, ++: strong, +: moderate, \pm : weak, - absent

${ }^{a}$ Obtained from selection against HS from bovine kidney after 10 min elution (MP4A11'10.b.k)

${ }^{\mathrm{b}}$ Obtained from selection against HS from bovine kidney after additional 20 min elution (MP3B2'20.b.k)

HS b.k.: heparan sulfate from bovine kidney; HS i.m.: heparan sulfate from porcine intestinal mucosa; DS: dermatan sulfate; CSA: chondroitin sulfate A; CSC: chondroitin sulfate C; DNA: deoxyribonucleic acid 
Table 6 Reactivity of selected anti-HS scFv antibodies against modified heparin preparations, as assessed by ELISA

\begin{tabular}{llllllll}
\hline & MP3C1 & MP4A11 & MP3B2 & MP4F11 & MP3G7 & MP4G5 & MP3A5 \\
\hline Heparin & + & + & ++ & ++ & & ++ & ++ \\
N-desulfated/N-acetylated heparin & - & - & - & + & + & + \\
2- $O$ desulfated heparin & - & + & - & ++ & + & - \\
6 - $O$ desulfated heparin & & + & + & - & ++ & ++ & ++ \\
\hline
\end{tabular}

Reactivity: +++: very strong, ++: strong, +: moderate, \pm : weak, - absent

${ }^{a}$ Obtained from selection against HS from bovine kidney after 10 min elution (MP4A11'10.b.k.)

${ }^{\mathrm{b}}$ Obtained from selection against HS from bovine kidney after additional 20 min elution (MP3B2'20.b.k.)

c $23 \%$ of $6-\mathrm{O}$ sulfate still present

HS: Heparan sulfate

\section{Antibody characterization}

From the library, 67 new scFv antibodies against HS were selected, indicating the versatility of the library. The biosynthesis of
HS allows for a large number of motifs and patterns within the molecule. The initial HS backbone consists of repeating disaccharide units composed of a glucuronic acid and an N-acetyl glucosamine. The acetyl group of the N-acetyl glucosamine
Fig. 2 Immunofluorescent staining of rat kidney cryosections with selected antiHS scFv antibodies indicate three distinct types of staining patterns. Staining type 1 (A, antibody MP3C1) comprises staining of the glomerulus (red/white arrow) and peritubular capillaries (blue arrow); staining type 2 (B, antibody MP4A11'10.b.k.) primarily comprises staining with Bowman's capsule (yellow arrow); staining type 3 (C, antibody MP4F11) comprises staining of the glomerulus, the peritubular capillaries and Bowman's capsule. Control antibody HS4C3 (D) results in type 1 staining. Antibody MPB49 (E) does not recognize a HS epitope in rat kidney sections HS: heparan sulfate.
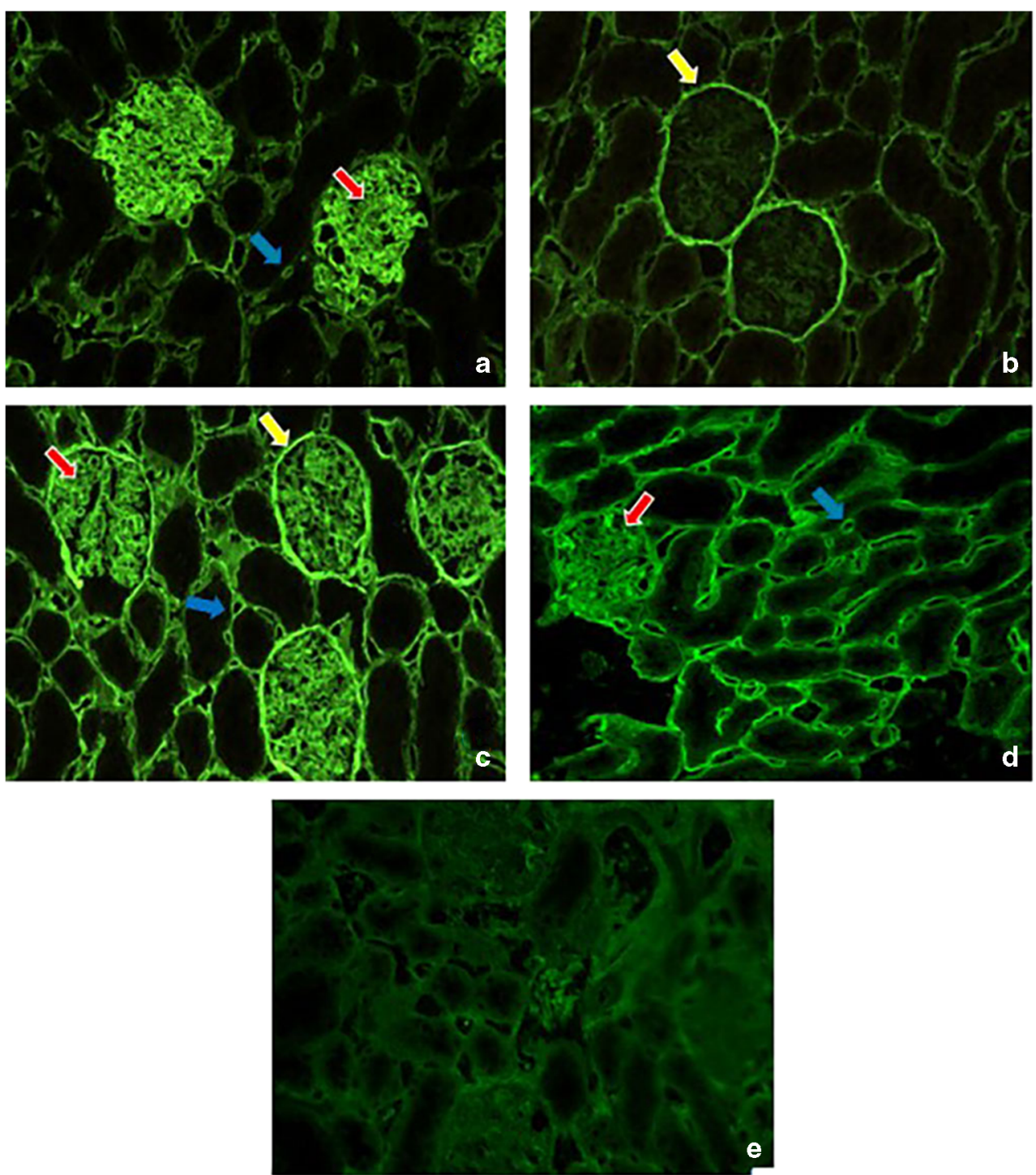
Table 7 Distribution of HS-epitopes in rat kidney defined by selected antibodies as assessed by immunohistochemistry

\begin{tabular}{lllllllll}
\hline & MP3C1 & MP4A11 & MP3B2 & MP4F11 & MP3G7 & MP4G5 & MP3A5 & HS4C3 \\
\hline Glomerular capillary tuft & ++ & - & ++ & ++ & \pm & & + & + \\
Glomerular mesangium & + & - & ND & + & + & + & + & + \\
Bowman's capsule & - & ++ & - & + & ++ & + & + & - \\
Peritubular capillaries & + & \pm & + & + & + & + & + \\
\hline
\end{tabular}

Staining: ++: strong, +: moderate, \pm : weak, - absent

${ }^{a}$ Obtained from selection against HS from bovine kidney after 10 min elution

${ }^{\mathrm{b}}$ Obtained from selection against HS from bovine kidney after additional 20 min elution

ND: no data; HS: heparan sulfate

can be exchanged for a sulfate group, initiating further modifications including epimerization of a glucuronic acid into an iduronic acid, the addition of a sulfate group to the $\mathrm{C} 2$ hydroxyl group of the uronic acid, and the addition of sulfates to the C6 and C3 hydroxyl groups of the glucosamine. Since these modifications occur in clustered regions, HS consists of low and highly sulfated domains. As a result, HS has a large structural variability and many different sulfation patterns are possible $[1,2$, 41]. With the new library, we aimed to obtain $\mathrm{scFv}$ antibodies directed against the different HS epitopes. We analyzed the reactivity of 67 anti-HS scFv antibodies with modified heparin preparations and studied the HS epitope in rat kidney sections. A number of antibodies had a distinct reaction profile. For instance, antibody MP3B2'20.b.k. did not react with $\mathrm{N}, 2-O$ or $6-O$ desulfated heparin preparations and strongly stained the kidney glomerulus, but not Bowman's capsule. On the other hand, antibody MP4A11 reacted with 2-O, and 6- $O$ desulfated heparin, but not with $\mathrm{N}$-desulfated (N-acetylated) heparin, and stained Bowman's capsule, but not the glomerulus. Antibody MP4F11 reacted with all desulfated heparin preparations and stained the glomerulus as well as Bowman's capsule. This suggests that e.g. antibody MP3B2'20.b.k. recognizes a highly sulfated HS domain, whereas antibody MPF11 recognizes a low sulfated region. Clearly, more in depth studies are needed to specify the exact nature of the HS structure(s) recognized by the antibodies. New developments in HS microarrays and cell-based HS libraries offer potential to do such analyses [42-44].

\section{Anti-HS scFvs on design}

In this study we aimed to obtain new anti-HS scFv directed towards different HS-epitopes by engineering the CDR3. Since this approach was successful, applying specific modifications to the anti-HS scFvs may prove to be effective to obtain antibodies against specific sulfation patterns. These modifications may not be limited towards the CDR3, since regions located outside the linear heparin binding site have been demonstrated to influence HS binding [45-47]. Knowledge on the specific amino acids involved in HS binding may allow for a rational design of antibodies targeting specific sulfation patterns. Strategies such as "protect and label" can identify essential amino acids involved in HS binding [48]. Once identified, site-directed mutagenesis of the CDR3 and other regions within $\mathrm{V}_{\mathrm{H}}$ and/or $\mathrm{V}_{\mathrm{L}}$ may result in the generation of anti-HS scFvs recognizing specific sulfation patterns. These tools may be instrumental in elucidating of the function of HS sulfation patterns in (patho)physiological processes.

In conclusion, we successfully constructed a new anti-HS scFv library, engineering the CDR3 to contain the heparinbinding consensus site XBBXBX. The library may be a rich source of new antibodies directed against different HS-epitope, and may allow the design of novel antibodies recognizing specific sulfation patterns.

Acknowledgements We express gratitude to prof. G. Winter, Cambridge University (Cambridge, United Kingdom) for providing the original phage display library. In addition, we are grateful to dr. A. Naggi and prof. B. Casu (G. Ronzoni Institute for Chemical and Biochemical Research, Milan, Italy) for providing the modified heparins. Finally, we express our gratitude to Karin Spreeuwenberg, Martijn Pieffers, Michel Dennissen and Toon Smetsers for their involvement in developing the phage display library.

Funding This work was supported by the European Union (ArrestAD, H2020-FETOPEN, grant number 737390).

\section{Compliance with ethical standards}

Conflicts of interest The authors declare that they have no conflicts of interest.

Ethical approval This article does not contain any studies with human participants or animals performed by any of the authors.

Open Access This article is licensed under a Creative Commons Attribution 4.0 International License, which permits use, sharing, adaptation, distribution and reproduction in any medium or format, as long as you give appropriate credit to the original author(s) and the source, provide a link to the Creative Commons licence, and indicate if changes were made. The images or other third party material in this article are included in the article's Creative Commons licence, unless indicated otherwise in a credit line to the material. If material is not included in the article's Creative Commons licence and your intended use is not 
permitted by statutory regulation or exceeds the permitted use, you will need to obtain permission directly from the copyright holder. To view a copy of this licence, visit http://creativecommons.org/licenses/by/4.0/.

\section{References}

1. Rabenstein, D.L.: Heparin and heparan sulfate: structure and function. Nat. Prod. Rep. 19(3), 312-331 (2002)

2. S. Sarrazin, W.C. Lamanna, J.D.: Heparan sulfate proteoglycans. Cold Spring Harbor perspectives in biology 3(7) (2011). doi:https:// doi.org/10.1101/cshperspect.a004952

3. Ornitz, D.M., Itoh, N.: The fibroblast growth factor signaling pathway. Wiley Interdiscip. Rev. Dev. Biol. 4(3), 215-266 (2015). https://doi.org/10.1002/wdev.176

4. Liu, J., Pedersen, L.C.: Anticoagulant heparan sulfate: structural specificity and biosynthesis. Appl. Microbiol. Biotechnol. 74(2), 263-272 (2007). https://doi.org/10.1007/s00253-006-0722-x

5. Hwang, J.A., Kim, Y., Hong, S.H., Lee, J., Cho, Y.G., Han, J.Y., Kim, Y.H., Han, J., Shim, Y.M., Lee, Y.S., Kim, D.H.: Epigenetic inactivation of heparan sulfate (glucosamine) 3-O-sulfotransferase 2 in lung cancer and its role in tumorigenesis. PLoS One. 8(11), e79634 (2013). https://doi.org/10.1371/journal.pone.0079634

6. Snow, A.D., Mar, H., Nochlin, D., Sekiguchi, R.T., Kimata, K., Koike, Y., Wight, T.N.: Early accumulation of heparan sulfate in neurons and in the beta-amyloid protein-containing lesions of Alzheimer's disease and Down's syndrome. Am. J. Pathol. 137(5), 1253-1270 (1990)

7. Sepulveda-Diaz, J.E., Alavi Naini, S.M., Huynh, M.B., Ouidja, M.O., Yanicostas, C., Chantepie, S., Villares, J., Lamari, F., Jospin, E., van Kuppevelt, T.H., Mensah-Nyagan, A.G., Raisman-Vozari, R., Soussi-Yanicostas, N., Papy-Garcia, D.: HS3ST2 expression is critical for the abnormal phosphorylation of tau in Alzheimer's disease-related tau pathology. Brain J. Neurol. 138(Pt 5), 1339-1354 (2015). https://doi.org/10.1093/ brain/awv056

8. Nissim, A., Hoogenboom, H.R., Tomlinson, I.M., Flynn, G., Midgley, C., Lane, D., Winter, G.: Antibody fragments from a 'single pot' phage display library as immunochemical reagents. EMBO J. 13(3), 692-698 (1994)

9. van Kuppevelt, T.H., Jenniskens, G.J., Veerkamp, J.H., ten Dam, G.B., Dennissen, M.A.: Phage display technology to obtain antiheparan sulfate antibodies. Methods in molecular biology (Clifton, NJ). 171, 519-534 (2001). https://doi.org/10.1385/159259-209-0:519

10. Smits, N.C., Lensen, J.F., Wijnhoven, T.J., Ten Dam, G.B., Jenniskens, G.J., van Kuppevelt, T.H.: Phage display-derived human antibodies against specific glycosaminoglycan epitopes. Methods Enzymol. 416, 61-87 (2006). https://doi.org/10.1016/ s0076-6879(06)16005-x

11. Ten Dam, G.B., Kurup, S., van de Westerlo, E.M., Versteeg, E.M., Lindahl, U., Spillmann, D., van Kuppevelt, T.H.: 3-O-sulfated oligosaccharide structures are recognized by anti-heparan sulfate antibody HS4C3. J. Biol. Chem. 281(8), 4654-4662 (2006). https://doi. org/10.1074/jbc.M506357200

12. Kurup, S., Wijnhoven, T.J., Jenniskens, G.J., Kimata, K., Habuchi, H., Li, J.P., Lindahl, U., van Kuppevelt, T.H., Spillmann, D.: Characterization of anti-heparan sulfate phage display antibodies AO4B08 and HS4E4. J. Biol. Chem. 282(29), 21032-21042 (2007). https://doi.org/10.1074/jbc.M702073200

13. van Kuppevelt, T.H., Dennissen, M.A., van Venrooij, W.J., Hoet, R.M., Veerkamp, J.H.: Generation and application of type-specific anti-heparan sulfate antibodies using phage display technology. Further evidence for heparan sulfate heterogeneity in the kidney The Journal of biological chemistry. 273(21), 12960-12966 (1998)
14. Dennissen, M.A., Jenniskens, G.J., Pieffers, M., Versteeg, E.M., Petitou, M., Veerkamp, J.H., van Kuppevelt, T.H.: Large, tissueregulated domain diversity of heparan sulfates demonstrated by phage display antibodies. J. Biol. Chem. 277(13), 10982-10986 (2002). https://doi.org/10.1074/jbc.M104852200

15. van de Westerlo, E.M., Smetsers, T.F., Dennissen, M.A., Linhardt, R.J., Veerkamp, J.H., van Muijen, G.N., van Kuppevelt, T.H.: Human single chain antibodies against heparin: selection, characterization, and effect on coagulation. Blood. 99(7), 2427-2433 (2002)

16. Z.A. Ahmad, S.K. Yeap, A.M. Ali, W.Y. Ho, N.B. Alitheen, M. Hamid: scFv antibody: principles and clinical application. Clinical \& developmental immunology 2012, 980250 (2012). doi:https:// doi.org/10.1155/2012/980250

17. Smits, N.C., Robbesom, A.A., Versteeg, E.M., van de Westerlo, E.M., Dekhuijzen, P.N., van Kuppevelt, T.H.: Heterogeneity of heparan sulfates in human lung. Am. J. Respir. Cell Mol. Biol. 30(2), 166-173 (2004). https://doi.org/10.1165/rcmb.200301980C

18. Gomes Jr., R.R., Van Kuppevelt, T.H., Farach-Carson, M.C., Carson, D.D.: Spatiotemporal distribution of heparan sulfate epitopes during murine cartilage growth plate development. Histochem. Cell Biol. 126(6), 713-722 (2006). https://doi.org/10. 1007/s00418-006-0203-4

19. Smetsers, T.F., van de Westerlo, E.M., ten Dam, G.B., Overes, I.M., Schalkwijk, J., van Muijen, G.N., van Kuppevelt, T.H.: Human single-chain antibodies reactive with native chondroitin sulfate detect chondroitin sulfate alterations in melanoma and psoriasis. The Journal of investigative dermatology. 122(3), 707-716 (2004). https://doi.org/10.1111/j.0022-202X.2004.22316.x

20. Jenniskens, G.J., Oosterhof, A., Brandwijk, R., Veerkamp, J.H., van Kuppevelt, T.H.: Heparan sulfate heterogeneity in skeletal muscle basal lamina: demonstration by phage display-derived antibodies. J. Neurosci. 20(11), 4099-4111 (2000)

21. Rops, A.L., van den Hoven, M.J., Baselmans, M.M., Lensen, J.F., Wijnhoven, T.J., van den Heuvel, L.P., van Kuppevelt, T.H., Berden, J.H., van der Vlag, J.: Heparan sulfate domains on cultured activated glomerular endothelial cells mediate leukocyte trafficking. Kidney Int. 73(1), 52-62 (2008). https://doi.org/10.1038/sj.ki. 5002573

22. Sela-Culang, I., Kunik, V., Ofran, Y.: The structural basis of antibody-antigen recognition. Front. Immunol. 4, 302 (2013). https://doi.org/10.3389/fimmu.2013.00302

23. Jones, L.L., Colf, L.A., Stone, J.D., Garcia, K.C., Kranz, D.M.: Distinct CDR3 conformations in TCRs determine the level of cross-reactivity for diverse antigens, but not the docking orientation. Journal of immunology (Baltimore, Md : 1950). 181(9), 62556264 (2008)

24. Borg, N.A., Ely, L.K., Beddoe, T., Macdonald, W.A., Reid, H.H., Clements, C.S., Purcell, A.W., Kjer-Nielsen, L., Miles, J.J., Burrows, S.R., McCluskey, J., Rossjohn, J.: The CDR3 regions of an immunodominant $\mathrm{T}$ cell receptor dictate the 'energetic landscape' of peptide-MHC recognition. Nat. Immunol. 6(2), 171-180 (2005). https://doi.org/10.1038/ni1155

25. Caldwell, E.E., Nadkarni, V.D., Fromm, J.R., Linhardt, R.J., Weiler, J.M.: Importance of specific amino acids in protein binding sites for heparin and heparan sulfate. Int. J. Biochem. Cell Biol. 28(2), 203-216 (1996)

26. Hileman, R.E., Fromm, J.R., Weiler, J.M., Linhardt, R.J.: Glycosaminoglycan-protein interactions: definition of consensus sites in glycosaminoglycan binding proteins. BioEssays : news and reviews in molecular, cellular and developmental biology. 20(2), 156-167 (1998). https://doi.org/10.1002/(sici)15211878(199802)20:2<156::Aid-bies8>3.0.Co;2-r

27. Kreuger, J., Jemth, P., Sanders-Lindberg, E., Eliahu, L., Ron, D., Basilico, C., Salmivirta, M., Lindahl, U.: Fibroblast growth factors 
share binding sites in heparan sulphate. The Biochemical journal. 389(Pt 1), 145-150 (2005). https://doi.org/10.1042/bj20042129

28. I. Capila, R.J. Linhardt: Heparin-protein interactions. Angewandte Chemie (International ed. in English) 41(3), 391-412 (2002)

29. Hof, D.J., Versteeg, E.M.M., van de Lest, C.H.A., Daamen, W.F., van Kuppevelt, T.H.: A versatile salt-based method to immobilize glycosaminoglycans and create growth factor gradients. Glycoconj. J. 36(3), 227-236 (2019). https://doi.org/10.1007/s10719-019-09872-4

30. Maccarana, M., Casu, B., Lindahl, U.: Minimal sequence in heparin/heparan sulfate required for binding of basic fibroblast growth factor. J. Biol. Chem. 268(32), 23898-23905 (1993)

31. Wijnhoven, T.J.M., Lensen, J.F.M., Rops, A.L.W.M.M., van der Vlag, J., Kolset, S.O., Bangstad, H.-J., Pfeffer, P., van den Hoven, M.J.W., Berden, J.H.M., van den Heuvel, L.P.W.J., van Kuppevelt, T.H.: Aberrant Heparan sulfate profile in the human diabetic kidney offers new clues for therapeutic Glycomimetics. Am. J. Kidney Dis. 48(2), 250-261 (2006). https://doi.org/10.1053/j.ajkd.2006.05.003

32. Torrent, M., Nogues, M.V., Andreu, D., Boix, E.: The "CPC clip motif": a conserved structural signature for heparin-binding proteins. PLoS One. 7(8), e42692 (2012). https://doi.org/10.1371/ journal.pone. 0042692

33. Xu, J.L., Davis, M.M.: Diversity in the CDR3 region of $\mathrm{V}(\mathrm{H})$ is sufficient for most antibody specificities. Immunity. 13(1), 37-45 (2000)

34. Schoonbroodt, S., Steukers, M., Viswanathan, M., Frans, N., Timmermans, M., Wehnert, A., Nguyen, M., Ladner, R.C., Hoet, R.M.: Engineering antibody heavy chain CDR3 to create a phage display fab library rich in antibodies that bind charged carbohydrates. Journal of immunology (Baltimore, Md : 1950). 181(9), 6213-6221 (2008)

35. Krilleke, D.: Ng, Y.-Shan E., Shima, David T.: the heparin-binding domain confers diverse functions of VEGF-A in development and disease: a structure-function study. Biochem. Soc. Trans. 37(6), 1201-1206 (2009). https://doi.org/10.1042/bst0371201

36. Trevino, S.R., Schaefer, S., Scholtz, J.M., Pace, C.N.: Increasing protein conformational stability by optimizing beta-turn sequence. J. Mol. Biol. 373(1), 211-218 (2007). https://doi.org/10.1016/j. jmb.2007.07.061

37. Moroy, G., Alix, A.J., Hery-Huynh, S.: Structural characterization of human elastin derived peptides containing the GXXP sequence. Biopolymers. 78(4), 206-220 (2005). https://doi.org/10.1002/bip. 20276

38. Booms, P., Ney, A., Barthel, F., Moroy, G., Counsell, D., Gille, C., Guo, G., Pregla, R., Mundlos, S., Alix, A.J., Robinson, P.N.: A fibrillin-1-fragment containing the elastin-binding-protein GxxPG consensus sequence upregulates matrix metalloproteinase-1: biochemical and computational analysis. J. Mol. Cell. Cardiol. 40(2), 234-246 (2006). https://doi.org/10.1016/j.yjmcc.2005.11.009
39. Moroy, G., Ostuni, A., Pepe, A., Tamburro, A.M., Alix, A.J., HeryHuynh, S.: A proposed interaction mechanism between elastin-derived peptides and the elastin/laminin receptor-binding domain. Proteins. 76(2), 461-476 (2009). https://doi.org/10.1002/prot.22361

40. Fuchs, P.F., Bonvin, A.M., Bochicchio, B., Pepe, A., Alix, A.J., Tamburro, A.M.: Kinetics and thermodynamics of type VIII betaturn formation: a CD, NMR, and microsecond explicit molecular dynamics study of the GDNP tetrapeptide. Biophys. J. 90(8), 27452759 (2006). https://doi.org/10.1529/biophysj.105.074401

41. Thacker, B.E., Xu, D., Lawrence, R., Esko, J.D.: Heparan sulfate $3-$ O-sulfation: a rare modification in search of a function. Matrix biology : journal of the International Society for Matrix Biology. 35, 60-72 (2014). https://doi.org/10.1016/j.matbio.2013.12.001

42. Yang, J., Hsieh, P.H., Liu, X., Zhou, W., Zhang, X., Zhao, J., Xu, Y., Zhang, F., Linhardt, R.J., Liu, J.: Construction and characterisation of a heparan sulphate heptasaccharide microarray. Chem Commun (Camb). 53(10), 1743-1746 (2017). https://doi.org/10. 1039/c6cc08204a

43. Chen, Y.H., Narimatsu, Y., Clausen, T.M., Gomes, C., Karlsson, R., Steentoft, C., Spliid, C.B., Gustavsson, T., Salanti, A., Persson, A., Malmstrom, A., Willen, D., Ellervik, U., Bennett, E.P., Mao, Y., Clausen, H., Yang, Z.: The GAGOme: a cell-based library of displayed glycosaminoglycans. Nat. Methods. 15(11), 881-888 (2018). https://doi.org/10.1038/s41592-018-0086-z

44. Qiu, H., Shi, S., Yue, J., Xin, M., Nairn, A.V., Lin, L., Liu, X., Li, G., Archer-Hartmann, S.A., Dela Rosa, M., Galizzi, M., Wang, S., Zhang, F., Azadi, P., van Kuppevelt, T.H., Cardoso, W.V., Kimata, K., Ai, X., Moremen, K.W., Esko, J.D., Linhardt, R.J., Wang, L.: A mutant-cell library for systematic analysis of heparan sulfate structure-function relationships. Nat. Methods. 15(11), 889-899 (2018). https://doi.org/10.1038/s41592-018-0189-6

45. Mulloy, B., Linhardt, R.J.: Order out of complexity-protein structures that interact with heparin. Curr. Opin. Struct. Biol. 11(5), 623$628(2001)$

46. Yamashita, H., Beck, K., Kitagawa, Y.: Heparin binds to the laminin alpha4 chain LG4 domain at a site different from that found for other laminins. J. Mol. Biol. 335(5), 1145-1149 (2004)

47. Khan, S., Gor, J., Mulloy, B., Perkins, S.J.: Semi-rigid solution structures of heparin by constrained X-ray scattering modelling: new insight into heparin-protein complexes. J. Mol. Biol. 395(3), 504-521 (2010). https://doi.org/10.1016/j.jmb.2009.10.064

48. Ori, A., Free, P., Courty, J., Wilkinson, M.C., Fernig, D.G.: Identification of heparin-binding sites in proteins by selective labeling. Molecular \& cellular proteomics : MCP. 8(10), 2256-2265 (2009). https://doi.org/10.1074/mcp.M900031-MCP200

Publisher's note Springer Nature remains neutral with regard to jurisdictional claims in published maps and institutional affiliations. 